\title{
1 Mature black alder shows intermittent events of high stem \\ 2 methane emissions
}

3 Daniel Köhn ${ }^{1 *}$, Anke Günther ${ }^{1}$, Ines Schwabe ${ }^{1}$, Gerald Jurasinski ${ }^{1}$

$4{ }^{1}$ University of Rostock, Landscape Ecology, Justus-von-Liebig-Weg 6, 18059 Rostock,

5 Germany

6 *daniel.koehn@uni-rostock.de Tel. +49 3814983233

7 ORCID iD: https://orcid.org/0000-0001-5435-8831

8

9

\section{Summary}

- Tree stems can be a source of the greenhouse gas methane $\left(\mathrm{CH}_{4}\right)$. However, assessments of the global importance are complicated by a lack of research and a high variability between ecosystems. Here, we determined the contribution of emissions from tree stems of mature black alder (Alnus glutinosa (L.) Gaertn.) to overall $\mathrm{CH}_{4}$ exchange in two temperate peatlands.

- We measured emissions from stems and soils using closed chambers in a drained and a wet alder forest over two years. Further, we studied the importance of alder leaves as substrate for methanogenesis in an incubation experiment.

- Stem $\mathrm{CH}_{4}$ emissions were shortlived and occurred only during times of inundation at the wet site. The drained site did not show stem emissions and the soil acted as a small $\mathrm{CH}_{4}$ sink. The contribution of stem emissions to the overall $\mathrm{CH}_{4}$ budget was below $0.3 \%$ in both sites.

- Our results show that also mature black alders intermittently can be a source of $\mathrm{CH}_{4}$. However, the low share of stem-mediated $\mathrm{CH}_{4}$ emissions in both forests may indicate that this pathway is only of minor relative importance in temperate peatlands.

Key words: Alnus glutinosa, methane $\left(\mathrm{CH}_{4}\right)$, stem fluxes, $\mathrm{CH}_{4}$ budgets, peatland

\section{Introduction}

Tree stems are increasingly recognized as potential surfaces for the exchange of greenhouse gases (GHG) such as methane $\left(\mathrm{CH}_{4}\right)$ (Pangala et al., 2013, 2015). $\mathrm{CH}_{4}$ is a potent $\mathrm{GHG}$ whose 
globally relevant emission sources are not yet fully understood (Melton et al., 2013; Saunois et al., 2016). It is possible that tree stems are a source that has been previously overlooked in global $\mathrm{CH}_{4}$ inventories (Pangala et al., 2017). Accordingly, emissions from trees have been discussed as a "new frontier in the global carbon cycle" (Barba et al., 2018).

Regionally, tree stem emissions can be the most important $\mathrm{CH}_{4}$ source (e.g. in the amazon basin, Pangala et al. 2017). However, the magnitude of $\mathrm{CH}_{4}$ fluxes from tree stems seems to vary considerably on a global scale with fluxes tending to be lower in temperate (Gauci et al., 2010; Pitz et al., 2018) than in tropical regions(Pangala et al., 2017). The ecosystem share of stem $\mathrm{CH}_{4}$ emissions has only rarely been addressed, with the few available studies reporting shares between $27 \%$ in a temperate and $87 \%$ in a tropical wetland (Pangala et al., 2013, 2015).

Although $\mathrm{CH}_{4}$ emissions from tree stems could be an emission pathway of global relevance, little information is available on the influence of ecosystem type or of abiotic factors. e.g. water level and soil temperature. Also, the variability of stem emissions between and within individual trees, e.g. caused by stem height, tree age or tree species, has rarely been studied (Barba et al., 2018).

Abiotic and biotic factors can influence both $\mathrm{CH}_{4}$ production itself and its emission rate from tree stems. Generally, soil temperature, soil water content or water level and physiological activity of the trees are assumed to be the most important influencing factors (Terazawa et al., 2015; Barba et al., 2019; Schindler et al., 2020). Accordingly, a considerable increase in stem $\mathrm{CH}_{4}$ emissions may be associated with increasing water tables (Pitz et al., 2018; Schindler et $a l ., 2020$ ) and increasing soil and air temperatures (Barba et al., 2019). This is further backed by mesocosm experiments (Rusch \& Rennenberg, 1998; Pangala et al., 2014).

The origin of the emitted $\mathrm{CH}_{4}$ likely can be either the tree trunk itself or the soil. Several studies found stems of upland trees to be sources of $\mathrm{CH}_{4}$ despite standing on very dry soils (Machacova et al., 2016; Wang et al., 2016; Maier et al., 2017; Pitz \& Megonigal, 2017). Thus, heartwood rot can be a good indicator for stem $\mathrm{CH}_{4}$ emissions (Covey et al., 2012; Wang et al., 2016). In addition, methanogenesis may even take place in aerobic parts of plant tissue (Bartlett et al., 2006; Bižić et al., 2020). On the other hand, $\mathrm{CH}_{4}$ produced in the soil can enter the tree through the roots and may be transported through the sap or through air-filled spaces in the trunk (Schröder, 1989). This is supported by several studies finding higher $\mathrm{CH}_{4}$ emissions in the lowest parts of the trunk (Terazawa et al., 2007; Barba et al., 2019; Schindler et al., 2020). 
Trees like black alder (Alnus glutinosa (L.) Gaertn.) additionally have the ability to transport oxygen into their rhizosphere and thereby stimulate methantrophy (Joabsson \& Christensen, 2001). In addition, alders predominantly grow on peat soils in temperate regions, which themselves have a high potential for $\mathrm{CH}_{4}$ emissions (Turetsky et al., 2014).

Black alder forests roughly cover 5\% of all central European forests (Claessens et al., 2010). In north-eastern Germany black alder is the second most important deciduous tree species after the European beech (Fagus sylvatica L.). In addition, the importance of black alder could increase further since it has a high potential for sustainable silviculture on rewetted peatlands (Schäfer et al., 2005).

Here, we study patterns of $\mathrm{CH}_{4}$ emissions through stems of mature black alders and relate them to soil $\mathrm{CH}_{4}$ emissions to evaluate the share of $\mathrm{CH}_{4}$ passing through trees in two temperate alder forests over two years. One of the studied forests is currently drained while the other is undrained (i.e. wet). Further, we studied the possible effects of leaf fall on soil $\mathrm{CH}_{4}$ emissions by determining $\mathrm{CH}_{4}$ production potentials in an incubation experiment. Our hypotheses are:

(1) $\mathrm{CH}_{4}$ emissions from stems of black alder contribute significantly to the overall $\mathrm{CH}_{4}$ budget.

(2) Absolute values of tree stem $\mathrm{CH}_{4}$ emissions of the wet site are larger than at the drained site, while relative contributions are higher at the drained site due to low or no emissions from the soil.

(3) Events like inundation, leaf fall or leaf out significantly increase stem $\mathrm{CH}_{4}$ emissions, because inundation increases $\mathrm{CH}_{4}$ production, leaf fall provides substrate for methanogenesis and leaf out increases rates of internal transport in the tree due to higher transpiration.

\section{Material and Methods}

\section{Study sites}

The drained and wet black alder forest sites are located in north-eastern Germany ( $54^{\circ} 7^{\prime} 36.27^{\prime \prime}$ $\mathrm{N}, 12^{\circ} 28^{\prime} 55.5^{\prime}$ E) sharing a distance of approx. $1 \mathrm{~km}$. The drained site has been logged for over 200 and most likely drained even earlier. After decades of drainage the wet site has gradually been rewetted since the 1990s with the final water levels establishing in 2004. Both sites are located approx. 40 m.a.s.l. and receive $627 \mathrm{~mm}$ of rain on average (DWD, reference period: 1981-2010) with annual mean temperature of $8.5^{\circ} \mathrm{C}$. Both sites are situated in local depressions. The research sites are fenced areas of approx. 12 × 30 m with a boardwalk running 
bioRxiv preprint doi: https://doi.org/10.1101/2020.09.01.277350; this version posted September 2, 2020. The copyright holder for this preprint (which was not certified by peer review) is the author/funder, who has granted bioRxiv a license to display the preprint in perpetuity. It is made available under aCC-BY-ND 4.0 International license.

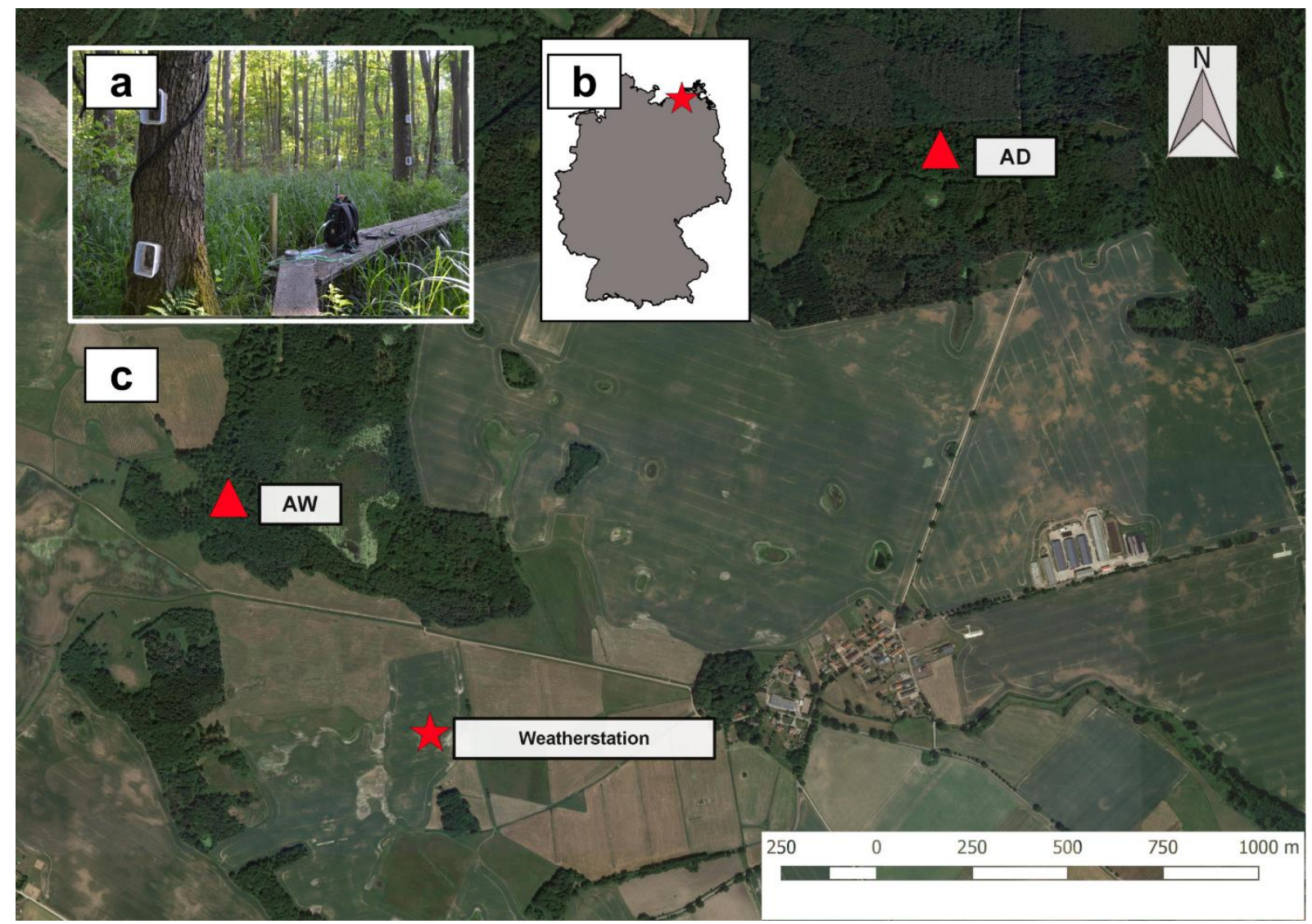

Abbildung 1 Fig. 1: a) Setup of tree chambers and Picarro Gas Scouter at AW. b) Study location in Germany. c) Location of $\mathrm{AW}, \mathrm{AD}$ and the weatherstation

Black alder (Alnus glutinosa (L.) Gaertn.) is the only tree species in the wet site (AW - Alder Wet). The understorey features sedges (Carex acutiformis Ehrh.), C. riparia Curtis), featherfoil (Hottonia palustris L.) and bitter nightshade (Solanum dulcamara L.). However, temporal flooding created areas of open water. Peat depth is around $2 \mathrm{~m}$ with an average soil $\mathrm{pH}$ of around 5.1. Soil carbon and phosporus contents lie at $38 \%$ and $1.4 \%$, respectively (Jurasinski et al., 2020).

The drained site (AD - Alder Dry) features a mixed stand of black alder and European ash (Fraxinus excelsior L.). The understory mainly comprises nettle (Urtica dioica L.), elderberry (Sambucus nigra L.) and blackberry (Rubus sp L.). In spring lesser calendine (Ranunculus ficaria (HUDS.)) is dominant on the ground. The peat is very shallow with a depth of approximately $40 \mathrm{~cm}$. Soil $\mathrm{pH}$ is 4.5 with soil carbon and phosphorus content being $19 \%$ and $2.7 \%$, respectively (Jurasinski et al., 2020). 
111 We used flow-through non-steady-state chambers to measure gas exchange between the 112 atmosphere and the stem as well as the soils surface, respectively (Livingston \& Hutchinson, 113 1995). We measured soil exchange fluxes in both sites at five different spots with permanently 114 installed PVC collars in the ground (approx. $10 \mathrm{~cm}$ depth, radius $=65 \mathrm{~cm}$, height $=0.9-1.4$ $115 \mathrm{~m})$ (Günther et al., 2014). Soil chambers were equipped with three fans at the lid as well as a 116 temperature and humidity sensor. Stem chambers were permanently installed on three trees at 117 three heights above the base of the stem (approx. $0.3 \mathrm{~m}, 1 \mathrm{~m}, 2 \mathrm{~m}$ ) at each site (i.e. 9 chambers 118 per site). We constructed the stem chambers using polypropylene containers from which the 119 bottom was cut out (EMSA $\left.{ }^{\circledR} \mathrm{V}=0.001 \mathrm{~m}^{3}\right)$. The chambers were mounted on the tree stems 120 with an adhesive synthetic sealant (plastic fermit ${ }^{\circledR}$, Fermit).

\section{Flux measurements}

122 Measurements were carried out every two weeks over the course of two years between May $3^{\text {rd }}$ 1232018 and April 30 ${ }^{\text {th }}$ 2020. On June 26 2018 we ran an 18-hour campaign to determine 124 differences in $\mathrm{CH}_{4}$ emissions from tree stems during day and night. In this campaign every stem 125 chamber was measured every 45 minutes.

126 For measurements of soil GHG exchange, the flexible side walls of the chamber were firmly attached to the PVC collar by a rubber band. For stem chamber measurements, the chamber was closed using a lid with a rubber gasket. Inlet and outlet tubes (PVC, inner diameter: 3.4 $\mathrm{cm})$ connected the chambers to a portable gas analyser. $\mathrm{CO}_{2}$ and $\mathrm{CH}_{4}$ concentrations inside the chamber were measured by laser spectrometers (Ultra-Portable Greenhouse Gas Analyzer, Los Gatos Research (C), and GasScouter, Picarro (C) with a measurement frequency of $1 \mathrm{~Hz}$.

132 Enclosure time for soil and stem chambers was 5 and 3 minutes, respectively. A shorter enclosure time for the stem chambers was chosen due to the much smaller headspace volume

$134\left(0.002 \mathrm{~m}^{3}\right.$ vs. $\left.0.31 \mathrm{~m}^{3}\right)$. Flux estimation was performed using R 3.6.4 (R development core team, 135 2020). For flux estimation we used an updated version of the fluxx() function of package flux 136 for R (Jurasinski et al., 2014). The slope was calculated between each concentration 137 measurement (one per second). Subsequently the median of the slope values was taken as an 138 estimate for the gas flux (i.e. median based regression (Siegel, 1982)).

\section{Additional measurements}

140 A weather station $500 \mathrm{~m}$ SW of the wet site (CR300, Campbell Scientific ${ }^{\circledR}$ ) recorded air 141 temperature, wind velocity, precipitation and radiation (PPFD). At both sites Onset ${ }^{\circledR}$ HOBO 142 Pendant soil temperature loggers were used at three different locations in 5 and $15 \mathrm{~cm}$ depth 
143 with a measurement interval of $15 \mathrm{~min}$. Water levels were logged continuously with a SEBA ${ }^{\circledR}$

144 CS457 dipper at 1 min intervals.

145 Methane budgets

146 Since we were not able to model methane fluxes using ancillary data, budgeting had to be based

147 on a statistical approach adapted from Günther et al., (2017).We used the area-under-curve

148 function (auc.mc) from the R package flux (Jurasinski et al. 2014) to integrate flux values over

149 time by linear interpolation. For each measurement day, one flux value per flux subset (stem or

150 soil) and each site (drained or wet) was randomly chosen. This was repeated 100 times to obtain

151100 different flux time series. Then, the area-under-curve was calculated 100 times for each

152 flux time series, each time leaving out one flux value (jackknife method), leading to a total of

15310000 different $\mathrm{CH}_{4}$ balances. For the final $\mathrm{CH}_{4}$ balances per site and flux subset we calculated

154 the average and standard deviation of all balances.

155 For determining the share of stem and soil mediated $\mathrm{CH}_{4}$ emissions, we projected the stem

156 emissions of the lower $2.2 \mathrm{~m}$ of the stem onto the base area of the respective tree trunks. The

157 upper limit of $2.2 \mathrm{~m}$ was chosen because we assumed that no $\mathrm{CH}_{4}$ was emitted from the tree

158 trunks above that height (see results). First, we measured the stem diameters of all sampled

159 trees once at the stem base and once at $2.2 \mathrm{~m}$ height. Then, we calculated the surface area of the

160 lower $2.2 \mathrm{~m}$ of each tree (A Surface$)$ by using equation (1) that assumes the tree trunk to be a

161 circular conical fustrum:

162

$$
A_{\text {Surface }}=\left(r_{\text {Base }}+r_{\text {Top }}\right) \times \pi \times \sqrt{\left(r_{\text {Base }}-r_{\text {Top }}\right)^{2}+h^{2}}
$$

163 where $r_{\text {Base }}$ and $r_{\text {Top }}$ are the base and top radii and $h$ is the height (2.2.m). The base area of each

164 tree trunk was calculated by equation (2):

$$
A_{\text {Base }}=\pi \times\left(r_{\text {Base }}\right)^{2}
$$

166 Finally, we calculated the stem $\mathrm{CH}_{4}$ flux projected to ground surface $\left(\mathrm{F}_{\text {Base }}\right)$ using equation (3)

$$
F_{\text {Base }}=\frac{F_{\text {Stem }} \times A_{\text {Surface }}}{A_{\text {Base }}}
$$

168 where $F_{\text {stem }}$ is the flux estimated from stem chambers relative to the stem area. Because no consensus exists on how to upscale stem fluxes, especially with regards to whether fluxes are upscaled on a stem or soil area basis we aimed at comparing three different approaches: 
A1. We used $F_{\text {Base }}$ to calculate annual balances and upscaled it with the approx. total base area of all trees per hectare.

A2. We used the daily average stem flux of each tree and multiplied it with the respective surface area of the stem which yields an average flux per tree and day. With this we also calculated annual balances.

A3. We used the overall average of stem fluxes and multiplied it with the total approx. stem surface area of all tree stems and projected it to the period of one entire year.

For each approach we calculated the share of stem emissions with regards to the total emissions of the ecosystem. For A1 and A2 we used the calculated balance for soil $\mathrm{CH}_{4}$ emissions for comparison. For $\mathrm{A} 3$ the overall average soil $\mathrm{CH}_{4}$ flux was taken for comparison. Soil $\mathrm{CH}_{4}$ fluxes and soil $\mathrm{CH}_{4}$ balances were spatially projected by multiplying with 1 ha excluding the base area of all trees per ha (AD: 273 trees ha ${ }^{-1}$ with $137 \mathrm{~m}^{2}$ base area, AW: 311 trees ha-1 with $106 \mathrm{~m}^{2}$ base area). Upscaling and the calculation of the share of stem $\mathrm{CH}_{4}$ emissions were done separately for AD and AW and each study year.

\section{Incubation experiment}

We complemented our field monitoring data with an incubation experiment to study the possible effects of leaf fall on soil $\mathrm{CH}_{4}$ emissions. For the incubation experiment soil samples were taken at both sites from the top soil $(0-10 \mathrm{~cm})$ in January 2020 and stored at approx. $5^{\circ} \mathrm{C}$ in a fridge for 9 days. Alder leaves were collected in fall 2018 and dried for 3 days at $60^{\circ} \mathrm{C}$ and subsequently stored in air tight plastic bags. Leaves were ground to $0.5 \mathrm{~mm}$ size. The incubation experiment comprised three different anaerobic incubations. We set up three incubation treatments to determine the $\mathrm{CH}_{4}$ production potential of soil and leaves separately and in combination. Hence, each incubation container $\left(140 \mathrm{ml}\right.$, Weck $\left.{ }^{\circledR}\right)$ received either $10 \mathrm{~g}$ soil (Soil only $_{\text {) }}$ or $50 \mathrm{mg}$ leaves (Leaves only) or a combination of $10 \mathrm{~g}$ soil and $50 \mathrm{mg}$ leaves (Soil

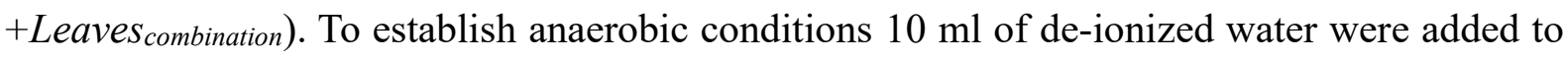
the containers, after which the containers were closed with a gas-tight lid. Then, the headspace was purged for 30 seconds with pure $\mathrm{N}_{2}$ gas. This procedure was repeated after each sampling. The anaerobic containers remained closed during the entire experiment.

In total, the experiment ran for 34 days. Gas samples were taken at two-day intervals at the beginning and later at four- to six-day intervals. Gas samples were taken from the containers with a $60 \mathrm{ml}$ syringe. Approximately $25 \mathrm{ml}$ headspace gas was added to evacuated $12 \mathrm{ml}$ Labco 
${ }^{\circledR}$ Exetainers. The analysis of the gas samples was carried out with a gas chromatograph

203 (Shimadzu Auto System) within three days after sampling.

204 The production potential of the control series was calculated as follows:

$$
\mathrm{P}_{\mathrm{p} \text {-Soil only | Leaves only) }}=\frac{\left(\mathrm{C}_{\mathrm{S}_{\mathrm{H}}}-\mathrm{C}_{\mathrm{a}} * \mathrm{~V}_{\mathrm{H}} * \mathrm{M}_{\mathrm{CH}_{4}}\right) / \mathrm{t}_{\mathrm{i}}}{\mathrm{V}_{\mathrm{M}}}+\frac{\left(\mathrm{C}_{\mathrm{L}_{\mathrm{H}}}-\mathrm{C}_{\mathrm{a}} * \mathrm{~V}_{\mathrm{H}} * \mathrm{M}_{\mathrm{CH}_{4}}\right) / \mathrm{t}_{\mathrm{i}}}{\mathrm{V}_{\mathrm{M}}}
$$

And the production potential of the priming series as follows:

$$
P_{p-\text { Soil }+ \text { Leaves combination }}=\frac{\left(C_{S+L_{H}}-C_{a} * V_{H^{*}} * M_{C H_{4}}\right) / t_{i}}{V_{M}} * m_{p}
$$

210 Where $\mathrm{C}_{\mathrm{SH}}$ and $\mathrm{C}_{\mathrm{LH}}$ are the $\mathrm{CH}_{4}$ concentrations in the headspace samples of the incubated soil and leaves, respectively. $\mathrm{C}_{\mathrm{S}+\mathrm{LH}}$ is the $\mathrm{CH}_{4}$ concentration in the headspace of the incubated combination of soil and leaves. $\mathrm{C}_{\mathrm{a}}$ is the starting concentration of $\mathrm{CH}_{4}$ (assumed to be 0 ), $\mathrm{V}_{\mathrm{H}}$

213 the headspace volume, $\mathrm{V}_{\mathrm{M}}$ the molar volume of $\mathrm{CH}_{4}\left(24.71 \mathrm{~mole}^{-1}\right.$ at $\left.25^{\circ} \mathrm{C}\right), \mathrm{M}_{\mathrm{CH} 4}$ the molar 214 mass of $\mathrm{CH}_{4}\left(16.04 \mathrm{~g} \mathrm{~mole}^{-1}\right)$ and $\mathrm{t}_{\mathrm{i}}$ the duration of the incubation. The production potential 215 was calculated in relation to the mass of the material that was incubated. Finally, the separate $216 \mathrm{CH}_{4}$ production potentials of Soil ${ }_{\text {only }}$ and Leaves only taken together were compared with 217 Soil+Leaves combination $_{\text {in }}$ order to prevent weight effects on the $\mathrm{CH}_{4}$ production potential.

\section{Statistical analyses}

219 Statisical analyses and visualizations were carried out with R 3.6.4 (R development core team, 220 2020). The entire datasets and subsets were tested for normality using Shapiro Wilk tests. We used Kruskal-Wallis tests to test for differences in means of the not normally-distributed data. Relationships between abiotic variables and $\mathrm{CH}_{4}$ fluxes were carried out with stepwise multiple linear regressions or exponential linear regressions.

\section{Results}

\section{Climate}

226 The study period was characterised by a large precipitation deficit together with above average temperatures compared to the respective average values of the climate period 1981-2010 (data

228 from the German Weather Service, DWD). In the first study year (May 2018-April 2019) the total precipitation was $381 \mathrm{~mm}$ (60\% of long-term average) and $424 \mathrm{~mm}$ (67\% of long-term average) in the second year (May 2019-April 2020) (Fig. 2). In both years, the deficit was

231 especially prevalent in spring and summer. The average air temperature was 10.4 and $10.9{ }^{\circ} \mathrm{C}$ 
232 for year one and two, respectively. This is 1.7 and $2.2^{\circ} \mathrm{C}$ above the annual mean temperature.

233 The water table was very variable at both the drained and the wet site.
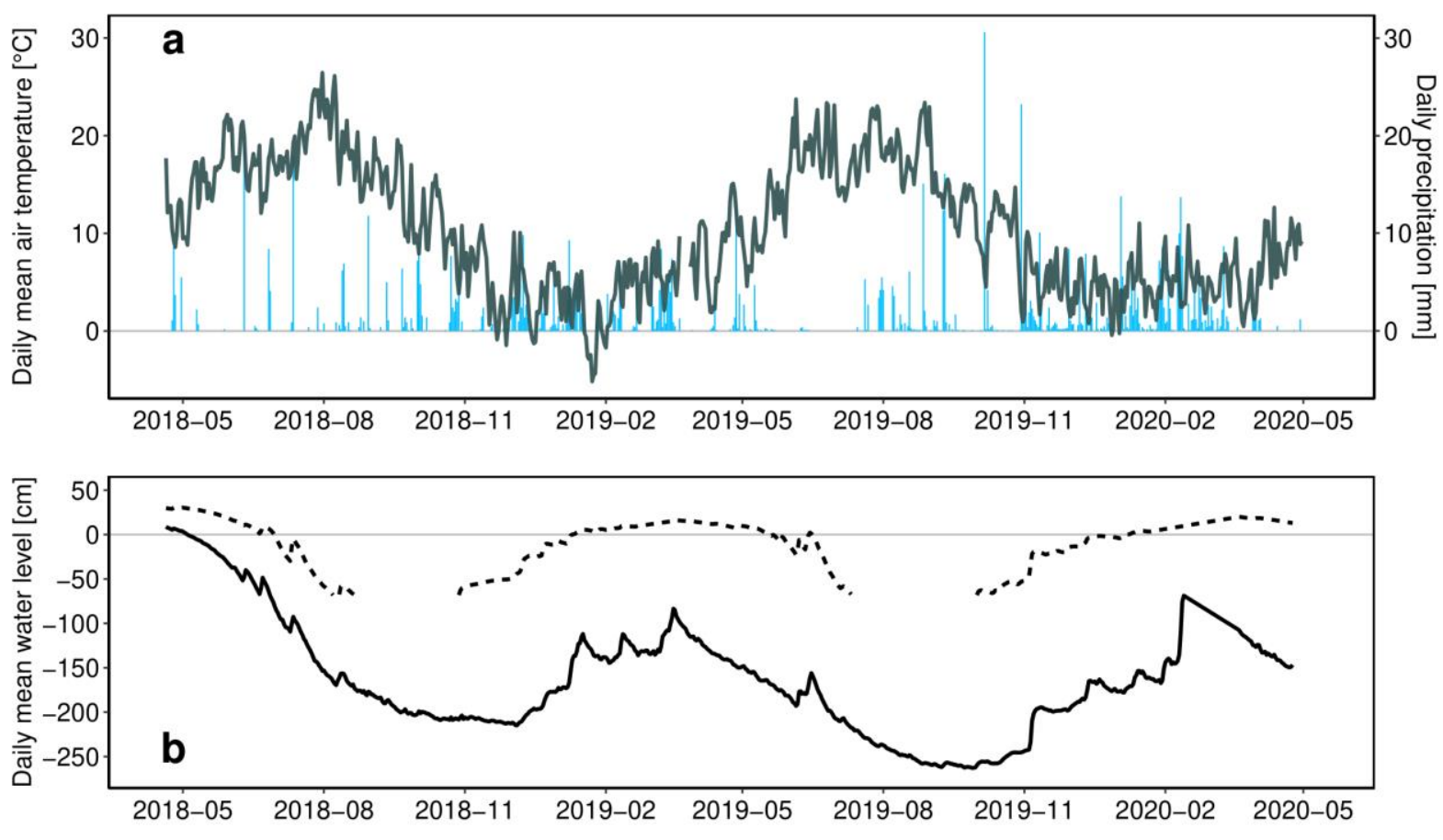

Abbildung 2 Fig. 2: a) Daily mean air temperature and daily precipitation. b) Daily mean water level in cm below soil surface. Solid line shows AD, dashed line shows AW. Gaps are present because the water level fell below the deepest point of the well.

\section{Flux measurements}

238 In total, 1167 stem flux and 414 soil flux measurements were conducted. Soil as well as stem

$239 \mathrm{CH}_{4}$ fluxes were significantly higher in AW than in AD $\left(\mathrm{p}<2.2 * 10^{-16}\right.$ and $\mathrm{p}=8.5^{*} 10^{-4}$, 240 respectively). During the study period, $\mathrm{AD}$ tended to show $\mathrm{CH}_{4}$ uptakeby the soil, with an average flux of $-0.07 \pm 0.12 \mathrm{mg} \mathrm{m}^{-2} \mathrm{~h}^{-1}$, while $\mathrm{CH}_{4}$ exchange was not visible at the tree stems.

242 Meanwhile, $\mathrm{CH}_{4}$ emissions were temporarily high both from the soil and the stem surface in 243 AW (average \pm SD: $4.8 \pm 18.8 \mathrm{mg} \mathrm{m}^{-2} \mathrm{~h}^{-1}$ and $0.07 \pm 0.34 \mathrm{mg} \mathrm{m}^{-2} \mathrm{~h}^{-1}$, respectively) without 244 showing a clear seasonal pattern. However, emissions from both stems and soil in AW were 245 very short lived and mostly lasted for only 6-8 weeks a year. The highest stem $\mathrm{CH}_{4}$ flux was $2464.0 \mathrm{mg} \mathrm{m}^{-2} \mathrm{~h}^{-1}$ (relative to stem area) on May $15^{\text {th }} 2018$ while the highest recorded soil $\mathrm{CH}_{4}$ flux 247 was $132.4 \mathrm{mg} \mathrm{m}^{-2} \mathrm{~h}^{-1}$ on June $29^{\text {th }} 2018$ (Fig. 3). An intensive measuring campaign over 18 248 hours of high-frequency measurements showed no diurnal pattern of $\mathrm{CH}_{4}$ emissions from the tree stems at AW (data not shown). Overall, $\mathrm{CH}_{4}$ emissions from the individual trees sampled in AW differed significantly from each other $\left(\mathrm{p}=3.2 * 10^{-3}\right)$. Despite a trend of decreasing stem 
$251 \mathrm{CH}_{4}$ emissions with increasing height (Fig. 4) the three different height groups were only

252 significantly different at one tree $\left(p=7.9 * 10^{-3}\right)$.

a

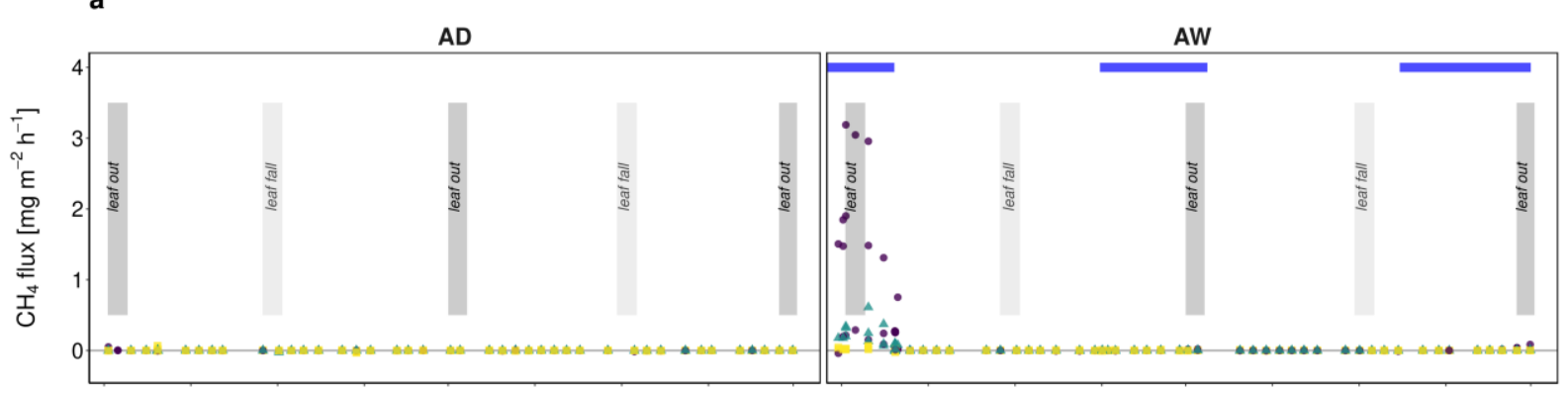

- $30-60 \mathrm{~cm} \triangle 90-120 \mathrm{~cm}=190-220 \mathrm{~cm}$

b

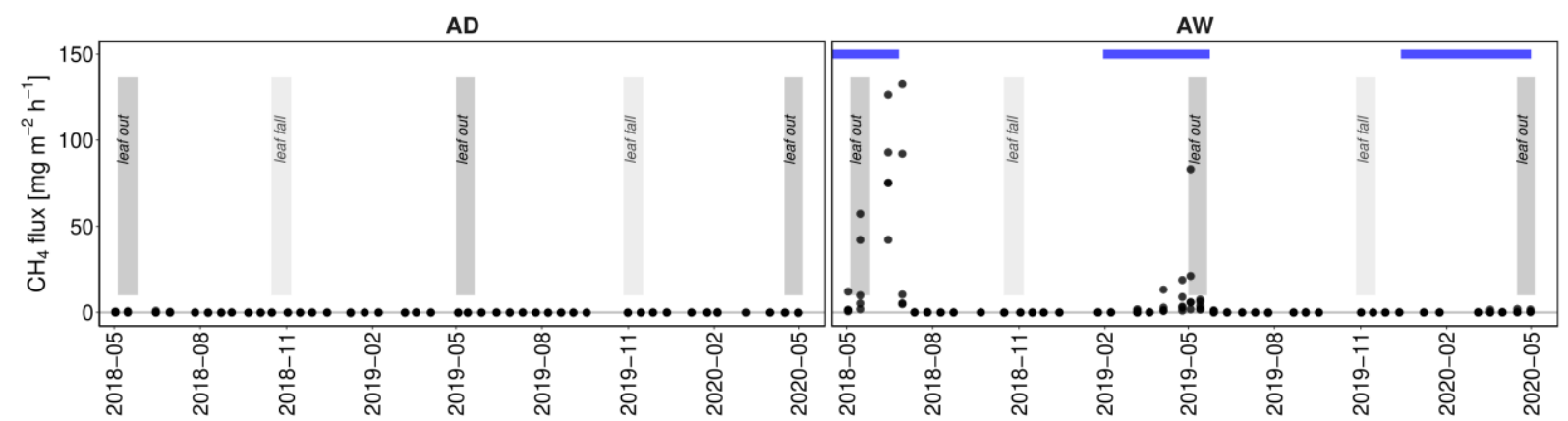

Fig. 3: Seasonal course of $\mathrm{CH}_{4}$ emissions from a) tree stem chambers by their height on the stem and b) soil chambers from $\mathrm{AD}$ and AW. Points indicate single measurements. Vertical grey bars depict period of leaf out and leaf fall. Horizontal blue bars indicate period of inundation at AW. Note different $y$-axes on $\mathbf{a}$ and $\mathbf{b}$.
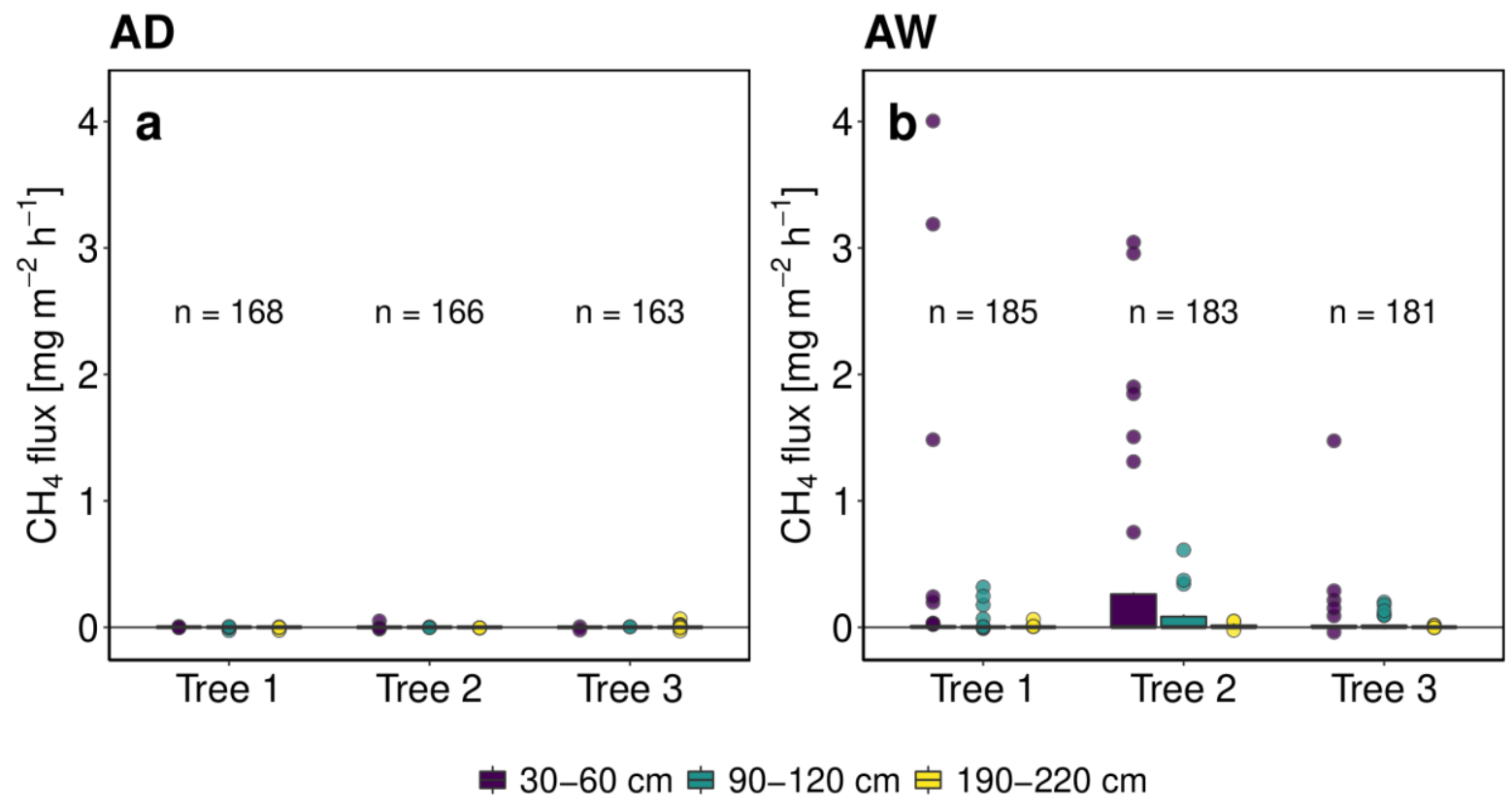

Fig. 4: Stem $\mathrm{CH}_{4}$ emissions by site a) $\mathrm{AD}$ and b) $\mathrm{AW}$ and height of chamber on the stem. 
At AW the diameter at breast height $(\mathrm{DBH})$ had a significant impact on stem $\mathrm{CH}_{4}$ fluxes $(\mathrm{p}=$ $3.2 * 10^{-3}$ ). During times when stem $\mathrm{CH}_{4}$ emissions could be detected, a weak exponential linear relationship between the height above the stem base (HASB) and stem emissions could be 264 observed $\left(\mathrm{R}^{2} 0.12, \mathrm{p}=1.3^{*} 10^{-6}\right)$. Due to the erratic patterns of the stem as well as of the soil $265 \mathrm{CH}_{4}$ emissions, relationships between soil temperature or air temperature were not apparent.

266 However, a significant exponential linear relationship between water level and stem as well as 267 soil $\mathrm{CH}_{4}$ emissions was observed at $\mathrm{AW}\left(\mathrm{R}^{2}=0.24, \mathrm{p}=2.2 * 10^{-16}\right.$ and $\mathrm{R}^{2}=0.22, \mathrm{p}=1.8 * 10^{-11}$, 268 respectively). Soil $\mathrm{CH}_{4}$ emissions tended to be highest when the water level was just above the 269 soil surface, while stem $\mathrm{CH}_{4}$ emissions were higher when the soil was inundated by approximately $25 \mathrm{~cm}$ (Fig. 3).

274 Annual $\mathrm{CH}_{4}$ budgets differed strongly between stem and soil surfaces and between measuring 275 years at AW. During year one the soil $\mathrm{CH}_{4}$ budget for AW was higher than for the second year 276 by a factor of 20 (Table 1 ).

277 Table 1: Absolute annual balances of stem CH4 emissions $( \pm \mathrm{SD})\left[\mathrm{kg} \mathrm{ha}^{-1} \mathrm{a}^{-1}\right]$ and the relative share $278[\%]$ of $\mathrm{AD}$ and $\mathrm{AW}$ and year one and two. Based on upscaling approaches A1, A2 and A3.

AD

\begin{tabular}{|c|c|c|c|c|c|c|}
\hline & \multicolumn{3}{|c|}{ Year 1} & \multicolumn{3}{|c|}{ Year 2} \\
\hline approach & soil $_{\text {absolute }}$ & stem $_{\text {absolute }}$ & share $_{\text {stem }}[\%]$ & soil $_{\text {absolute }}$ & stem $_{\text {absolute }}$ & share $_{\text {stem }}[\%]$ \\
\hline $\mathrm{A} 1$ & $-2.9 \pm 0.7$ & $0.002 \pm 0.002$ & 0.07 & $-6.8 \pm 0.3$ & $0.004 \pm 0.001$ & 0.06 \\
\hline A2 & $-2.9 \pm 0.7$ & $0.001 \pm 0.002$ & 0.03 & $-6.8 \pm 0.3$ & $0.004 \pm 0.001$ & 0.07 \\
\hline \multirow[t]{4}{*}{ A3 } & $-4.1 \pm 5.7$ & $0.007 \pm 0.063$ & 0.17 & $-7.8 \pm 13.2$ & $0.005 \pm 0.020$ & 0.05 \\
\hline & \multicolumn{6}{|c|}{$\mathbf{A W}$} \\
\hline & \multicolumn{3}{|c|}{ Year 1} & \multicolumn{3}{|c|}{ Year 2} \\
\hline & soil $_{\text {absolute }}$ & stem $_{\text {absolute }}$ & share $_{\text {stem }}[\%]$ & soil $_{\text {absolute }}$ & stem $_{\text {absolute }}$ & share $_{\text {stem }}[\%]$ \\
\hline A1 & $753 \pm 93$ & $1.2 \pm 0.1$ & 0.16 & $51 \pm 10$ & $0.01 \pm 0.001$ & 0.02 \\
\hline A2 & $753 \pm 93$ & $2 \pm 0.2$ & 0.26 & $51 \pm 10$ & $0.07 \pm 0.002$ & 0.14 \\
\hline A3 & $120 \pm 358$ & $0.17 \pm 0.75$ & 0.14 & $20 \pm 120$ & $0.004 \pm 0.014$ & 0.02 \\
\hline
\end{tabular}

280 All approaches yielded similar results in absolute balances as well as in the shares stem 281 emissions constitute. The overall shares of stem $\mathrm{CH}_{4}$ emissions were very low, not exceeding $2820.26 \%$ in any of the upscaling approaches. Overall, the share of stem-mediated $\mathrm{CH}_{4}$ emissions 283 decreased strongly in the second study year, despite decreasing soil $\mathrm{CH}_{4}$ emissions. 
284 Additionally, shares of stem-mediated $\mathrm{CH}_{4}$ emissions at $\mathrm{AD}$ are lower than in $\mathrm{AW}$, regardless 285 of the lower soil $\mathrm{CH}_{4}$ emissions.

\section{Leaf fall}

287 The incubation experiment revealed a clear enhancing effect of the addition of alder leaves on

288 the production potential of $\mathrm{CH}_{4}$. For incubations of Soil + Litter $_{\text {combination, }} \mathrm{CH}_{4}$ production increased by $924 \%$ and $774 \%$ in $\mathrm{AW}$ and AD, respectively, compared to $S_{\text {only }}+$ Leaves only (Fig. 5). An increase in $\mathrm{CH}_{4}$ production started following a four-day lag phase and peaked after 14

291 days. Thereafter, the production of $\mathrm{CH}_{4}$ decreased gradually and ceased after 30 days of 292 incubation. The production potential in Soil+Litter combination did not differ significantly between 293 the sites.

294 However, soil $\mathrm{CH}_{4}$ fluxes at both $\mathrm{AD}$ and AW showed no clear increase after leaf fall (Fig. 3). In 2018, $\mathrm{CH}_{4}$ fluxes at AW were even slightly lower within four weeks after leaf fall compared

296 to the four weeks prior leaf fall $\left(\mathrm{p}=3.3 * 10^{-3}\right)$. No significant difference of $\mathrm{CH}_{4}$ fluxes before 297 and after leaf fall could be observed at either of the other leaf fall events (AW in 2019, AD in 2982018 or in 2019).

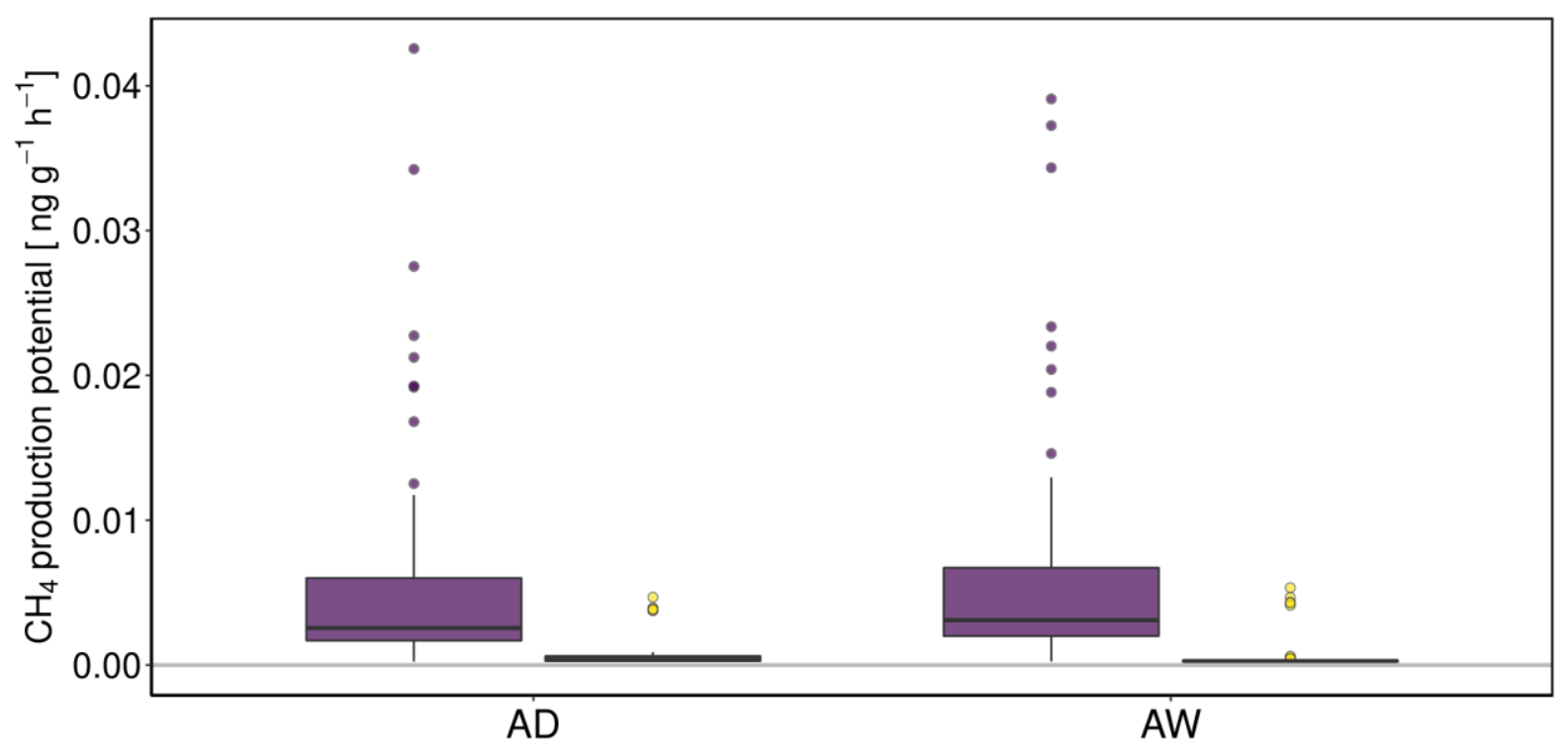




\section{Discussion}

305

306

307

308

309

The importance of stem-mediated $\mathrm{CH}_{4}$ emissions

Our results show that stems of mature black alder trees act as conduits for $\mathrm{CH}_{4}$ and can, at least temporarily, contribute a relevant share of overall ecosystem $\mathrm{CH}_{4}$ emissions. Overall, all upscaling approaches gave similarly low shares of stem emissions compared to other studies (Pangala et al., 2013, 2015). Only in $\mathrm{AD}$ where soil $\mathrm{CH}_{4}$ exchange mainly consisted of $\mathrm{CH}_{4}$ uptake, the results of the three approaches differed up to one order of magnitude. Even during the period of peak emissions in AW in spring 2018, ecosystem shares of stem $\mathrm{CH}_{4}$ emissions were lower than $0.33 \%$ due to the simultaneously very high soil $\mathrm{CH}_{4}$ emissions. Interestingly, $87 \%$ of all stem $\mathrm{CH}_{4}$ emissions in year one occurred in a two-month period between May $1^{\text {st }}$ and July $1^{\text {st }}$ of 2018 whereas only $7 \%$ of the total soil $\mathrm{CH}_{4}$ emissions were detected in the same period (calculated using approach A1). This suggests a potentially transient nature of stem $\mathrm{CH}_{4}$ emissions. For future studies it would be interesting to estimate the share of stem-mediated $\mathrm{CH}_{4}$ emissions in a constantly inundated alder forest where stem emissions may persist while soil emissions may be hampered by oxidation in the water column (Bastviken et al., 2002, 2008). In such environments, the importance of stem-mediated $\mathrm{CH}_{4}$ emissions could be much higher. As large parts of inundated swamps are covered by black alder and other wetland tree species, these ecosystems may still be of high importance for the regional $\mathrm{CH}_{4}$ budget.

Individual soil $\mathrm{CH}_{4}$ fluxes during spring 2018 were extremely high compared to other studies from temperate wetlands (Turetsky et al., 2014; Pangala et al., 2015). However, on average soil $\mathrm{CH}_{4}$ fluxes at $\mathrm{AW}$ in this study $\left(4.82 \mathrm{mg} \mathrm{m}^{-2} \mathrm{~h}^{-1}\right)$ fit very well to the approximate mean (4.54 $\mathrm{mg} \mathrm{m}^{-2} \mathrm{~h}^{-1}$ ) for emissions from temperate peatlands (Turetsky et al., 2014).

\section{Drained vs. undrained alder forest}

Despite drought conditions in both study sites, the wet alder forest (AW) on average had distinctively higher $\mathrm{CH}_{4}$ emissions from soil and stems than the drained forest. The results therefore support the high importance of water availability or water level for stem $\mathrm{CH}_{4}$ emissions (Pitz et al., 2018; Barba et al., 2019; Schindler et al., 2020). Interestingly, stems at $\mathrm{AD}$ did not emit $\mathrm{CH}_{4}$ and therefore did not offset the sink function of the soil, contrary to what was found at other dry forests (Wang et al., 2016; Pitz \& Megonigal, 2017).It is possibly that the trees were not connected to the groundwater as rooting depth of black alder varies considerably (Pietzarka \& Roloff, 2000), or that no $\mathrm{CH}_{4}$ was produced in the soil, due to low carbon content in lower soil layers. 
336 The influence of inundation, drought, leaf out and leaf fall on stem $\mathrm{CH} 4$ emissions

337 Our data indicates that most likely a combination of inundation, increasing temperatures and

338 increasing physiological activity of vegetation and/or microorganisms leads to higher emission

339 rates of $\mathrm{CH}_{4}$ from both soil and stem surfaces. This supports the most important influencing

340 factors for $\mathrm{CH}_{4}$ emissions from stems as found in other studies (Barba et al., 2018).

341 In spring 2019 no emissions could be measured at the stem surfaces and soil fluxes showed 342 only a relatively small emission peak that wasof a lower magnitude than the emission maximum 343 in early 2018 (Fig. 3). This may indicate that the drier conditions and shorter period of 344 inundation in spring 2019 compared to 2018 lead to lower $\mathrm{CH}_{4}$ production in the soil, and that 345 possibly thresholds regarding the duration of inundation must be exceeded before stem $\mathrm{CH}_{4}$ 346 emissions occur. Longer periods of inundation could be related to the time necessary for the 347 depletion of oxygen in the soil. Also, increases in methanogen activity may start with a lag time, 348 as shown in incubation experiments (Sun et al., 2012; Ye et al., 2015). During low 349 concentrations and production rates of $\mathrm{CH}_{4}$ (in the soil) the dominating mode of transport inside 350 the tree is likely to be passive diffusion (Kutschera et al., 2016). Hence, it could be assumed 351 that in 2019 when fluxes and presumably soil $\mathrm{CH}_{4}$ concentrations were generally lower, the $352 \mathrm{CH}_{4}$ first degassed via the soil-atmosphere interface, because the mode of transport was 353 relatively slow. Contrastingly, in 2018 the $\mathrm{CH}_{4}$ concentrations were higher, potentially 354 triggering another mode of transport (Kutschera et al., 2016) from the roots to the trunk 355 bypassing potential oxidative layers leading to higher stem fluxes. This, however is based upon the assumption that all $\mathrm{CH}_{4}$ is produced in the soil. The uncertainty regarding the transport processes again calls for future detailed parallel investigations of $\mathrm{CH}_{4}$ related processes in the soil, pore water and stem. Ideally, also matter turn-over and microbial community should be monitored in direct connection with flux measurements.

360 Climatic conditions during the study were very variable. generally, drought entirely stopped $\mathrm{CH}_{4}$ emissions from both stems and soil but fostered $\mathrm{CH}_{4}$ uptake in both sites. Conditions at AW even changed so drastically that despite previously showing strong emissions in June 2018 the soil repeatedly turned to a sink in the following summer with a maximum uptake of $-0.3 \mathrm{mg}$ $\mathrm{m}^{-2} \mathrm{~h}^{-1}$ in July 2019, similar to the uptake rate at AD. This effect could be explained by a high abundance of methanotrophic Bacteria and Archaea at AW (Weil et al., 2020). Since global warming increases climate variability and the likelihood for extreme events like drought and strong precipitation (King \& Karoly, 2017), the importance of stem $\mathrm{CH}_{4}$ emissions could be changed drastically in the future. Thus, long term monitoring and understanding of the driving 
factors in variable environmental conditions is still important to estimate the impact of stemmediated emissions.

371 The observed emission peaks took place parallel to leaf out of the black alder, indicating that 372 through a rise in activity and transpiration rates inside the tree possibly more $\mathrm{CH}_{4}$ could enter 373 the tree. Sap flow as a meter for transpiration can act as an explanatory variable for stem $\mathrm{CH}_{4}$ 374 emissions (Barba et al., 2019). Further, the results of Barba et al. (2019) suggest that increasing temperatures also directly lead to an increase in stem $\mathrm{CH}_{4}$ emissions. Thus, it is likely that a combination of sufficient water availability, sap flow intensity and rising temperatures led to peak stem $\mathrm{CH}_{4}$ emission in our study. Aside from sap flow intensity, stem $\mathrm{CO}_{2}$ emissions could be used as an indicator for respiration and hence indirectly for physiological activity of the tree (Hölttä \& Kolari, 2009; Machacova et al., 2019), that may explain stem $\mathrm{CH}_{4}$ emissions (Barba et al., 2017). However, in our study stem $\mathrm{CO}_{2}$ emissions at $\mathrm{AW}$ could only explain $1 \%$ of all $\mathrm{CH}_{4}$ fluxes larger than $0.1 \mathrm{mg} \mathrm{m}^{-2} \mathrm{~h}^{-1}$ (tested with linear models, data not shown). Thus, stem $\mathrm{CH}_{4}$ emissions in our study seem to be independent from physiological activity of the tree . This is further supported by our finding that fluxes did not vary over the course of the day (data not shown).

Additionally, our data suggests that individual differences in stem $\mathrm{CH}_{4}$ emissions between trees can be large, despite all trees being of similar size and of the same species (Fig. 4). Thus, other factors that were not considered in this study, both concerning the soil and the tree, may be of importance for stem $\mathrm{CH}_{4}$ emissions. Microbiological community and microtopography may influence local methanogenesis and, thus, pore water $\mathrm{CH}_{4}$ concentration in the rooting zone of the tree (Pangala et al., 2015; Terazawa et al., 2015). Physiological activity inside the tree (Zeikus \& Ward, 1974; Covey et al., 2012) or morphological parameters such as wood density could be responsible for significant differences between individual trees (Pangala et al., 2013). Here it would be useful to expand the study over the entire stand and sample for stem diameter and wood specific density.

395 Finally, as indicated by our incubation experiment leaf fall holds the potential to increase $\mathrm{CH}_{4}$ 396 production, probably by providing fresh substrate for methanogenesis. However, the results 397 from the incubation are not directly transferable to the field, as fluxes measured in the field did not increase in the weeks after leaf fall. In the field, both temperature and water availability 400 Hence, it is unlikely that in temperate regions leaf fall alone leads to $\mathrm{CH}_{4}$ emission peaks. 401 Therefore, the long-term effects of leaves on $\mathrm{CH}_{4}$ emissions should be studied in the future 
402 through combination of multiple-site leaf-exclusion and incubation/mesocosm experiments.

403 Especially alder stands that are directly connected with constant water bodies such as rivers and

404 lakes - as is often the case in north and central Europe (Claessens et al., 2010) - hold the

405 potential of being a constant overlooked mediator of $\mathrm{CH}_{4}$.

406 Conclusion

407 Data from this and other studies show that forests must not be overlooked in global $\mathrm{CH}_{4}$ 408 budgets. However, the importance of stem-mediated $\mathrm{CH}_{4}$ emissions may vary considerably 409 between individual ecosystems, even if dominated by the same tree species. The present study 410 shows that the variability of stem and soil $\mathrm{CH}_{4}$ emissions cannot be explained by a single 411 influential factor and likely differs strongly across ecosystems. Further, the interplay of all 412 variables involved demands future investigations. Although our findings suggest the soil to be 413 the origin of the $\mathrm{CH}_{4}$ coming from the stems the observed variability of this emission path and 414 the unknown transport mechanism inside the tree clearly ask for more mechanistic research 415 within this topic.

416 Acknowledgements

417 The authors thank field technicians, student assistants and volunteers for supporting the 418 measurement campaigns and maintaining the equipment.

419 Author Contributions: Design of the research: D.K., A.G and G.J.; field work was

420 conducted by: D.K., I.S.; data analysis, collection, or interpretation: D.K., A.G., I.S., G.J.;

421 writing the manuscript: D.K., A.G., G.J.

422 Funding: The European Social Fund (ESF) and the Ministry of Education, Science and Culture 423 of Mecklenburg-Western Pomerania (Germany) funded this work within the scope of the 424 project WETSCAPES (ESF/14-BM-A55-0034/16 and ESF/14-BM-A55-0030/16).

425 Conflicts of Interest: The authors declare no conflict of interest.

426 Data availability: Data is accessible via PANGAEA link:

427 https://issues.pangaea.de/browse/PDI-25060

References 
JP, Mikkelsen TN, Pangala SR, Pihlatie M, et al. 2018. Methane emissions from tree stems: a new frontier in the global carbon cycle. New Phytologist 222: 18-28.

2. Barba J, Poyatos R, Vargas R. 2017. Automated $\mathrm{CO}_{2}, \mathrm{CH}_{4}$ and $\mathrm{N}_{2} \mathrm{O}$ fluxes from tree stems and soils: magnitudes, temporal patterns and drivers. In: Fall Meeting, AGU, New Orleans, LA, USA, 11-15 December.

3. Barba J, Poyatos R, Vargas R. 2019. Automated measurements of greenhouse gases fluxes from tree stems and soils: magnitudes, patterns and drivers. Scientific Reports 9: $1-13$.

4. Bartlett KB, Harriss RC, Andersen BL, B G, Leip A, Rembges D, Bergamaschi P, Lubina C, Fischer H, Fisher RE, et al. 2006. Methane emissions from terrestrial plants under aerobic conditions. Nature 13: 445-461.

5. Bastviken D, Cole JJ, Pace ML, Van de-Bogert MC. 2008. Fates of methane from different lake habitats: Connecting whole-lake budgets and $\mathrm{CH}_{4}$ emissions. Journal of Geophysical Research: Biogeosciences 113: 1-13.

6. Bastviken D, Ejlertsson J, Tranvik L. 2002. Measurement of methane oxidation in lakes: A comparison of methods. Environmental Science and Technology 36: 33543361.

7. Bižić M, Klintzsch T, Ionescu D, Hindiyeh MY, Günthel M, Muro-Pastor AM, Eckert W, Urich T, Keppler F, Grossart HP. 2020. Aquatic and terrestrial cyanobacteria produce methane. Science Advances 6: 1-10.

8. Claessens H, Oosterbaan A, Savill P, Rondeux J. 2010. A review of the characteristics of black alder (Alnus glutinosa (L.) Gaertn.) and their implications for silvicultural practices. Forestry 83: 163-175.

9. Covey KR, Wood SA, Warren RJ, Lee X, Bradford MA. 2012. Elevated methane concentrations in trees of an upland forest. Geophysical Research Letters 39: 1-6. methane emission in mature wetland alder trees. Atmospheric Environment 44: $2157-$ 2160. Greenhouse gas balance of an establishing Sphagnum culture on a former bog grassland in Germany. Mires and Peat 20: Article 02. underestimate methane fluxes of Phragmites australis (Cav.) Trin. ex Steud. Environmental Monitoring and Assessment 186: 2151-2158. 
13. Hölttä T, Kolari P. 2009. Interpretation of stem $\mathrm{CO}_{2}$ efflux measurements. Tree Physiology 29: 1447-1456.

14. Joabsson A, Christensen TR. 2001. Methane emissions from wetlands and their relationship with vascular plants: an Arctic example. Global Change Biology 7: 919932.

\section{Jurasinski G, Ahmad S, Anadon-Rosell A, Berendt J, Beyer F, Bill R, Blume-} Werry G, Couwenberg J, Günther A, Joosten H, et al. 2020. From Understanding to Sustainable Use of Peatlands: The WETSCAPES Approach. Soil Systems 4: 1-27.

16. Jurasinski G, Koebsch F, Günther A, Beetz S. 2014. R package Flux.

17. King AD, Karoly DJ. 2017. Climate extremes in Europe at 1.5 and 2 degrees of global warming. Environmental Research Letters 12: 1-9.

18. Kutschera E, Khalil A, Rice A, Rosenstiel T. 2016. Mechanisms of methane transport through Populus trichocarpa. Biogeosciences Discussions 60: 1-17.

19. Livingston GP, Hutchinson GL. 1995. Enclosure-based measurement of trace gas exchange: applications and sources of error. In: Matson PA, Harris RC, eds. Biogenic Trace Gases: Measuring Emissions from Soil and Water. 14-53.

20. Machacova K, Bäck J, Vanhatalo A, Halmeenmäki E, Kolari P, Mammarella I, Pumpanen J, Acosta M, Urban O, Pihlatie M. 2016. Pinus sylvestris as a missing source of nitrous oxide and methane in boreal forest. Scientific Reports 6: 2-10.

21. Machacova K, Vainio E, Urban O, Pihlatie M. 2019. Seasonal dynamics of stem $\mathrm{N}_{2} \mathrm{O}$ exchange follow the physiological activity of boreal trees. Nature Communications: 1-13.

22. Maier M, Machacova K, Lang F, Svobodova K, Urban O. 2017. Combining soil and tree-stem flux measurements and soil gas profiles to understand $\mathrm{CH}_{4}$ pathways in Fagus sylvatica forests. Journal of Plant Nutrition and Soil Science.

23. Melton JR, Wania R, Hodson EL, Poulter B, Ringeval B, Spahni R, Bohn T, Avis CA, Beerling DJ, Chen G, et al. 2013. Present state of global wetland extent and wetland methane modelling: Conclusions from a model inter-comparison project (WETCHIMP). Biogeosciences 10: 753-788.

24. Pangala SR, Enrich-Prast A, Basso LS, Peixoto RB, Bastviken D, Hornibrook ERC, Gatti L V., Marotta H, Calazans LSB, Sakuragui CM, et al. 2017. Large emissions from floodplain trees close the Amazon methane budget. Nature 552: 230234.

25. Pangala SR, Gowing DJ, Hornibrook ERC, Gauci V. 2014. Controls on methane 
emissions from Alnus glutinosa saplings. New Phytologist 201: 887-896.

26. Pangala SR, Hornibrook ERC, Gowing DJ, Gauci V. 2015. The contribution of trees to ecosystem methane emissions in a temperate forested wetland. Global Change Biology 21: 2642-2654.

27. Pangala SR, Moore S, Hornibrook ERC, Gauci V. 2013. Trees are major conduits for methane egress from tropical forested wetlands. New Phytologist 197: 524-531.

28. Pietzarka U, Roloff A. 2000. Alnus glutinosa. In: Enzyklopädie der Holzgewächse. 1-16.

29. Pitz S, Megonigal JP. 2017. Temperate forest methane sink diminished by tree emissions. New Phytologist 214: 1432-1439.

30. Pitz SL, Megonigal JP, Chang CH, Szlavecz K. 2018. Methane fluxes from tree stems and soils along a habitat gradient. Biogeochemistry 137: 307-320.

31. $R$ development core team. 2020. R 3.6.4.

32. Rusch H, Rennenberg H. 1998. Black alder (Alnus glutinosa (L.) Gaertn.) trees mediate methane and nitrous oxide emission from the soil to the atmosphere. Plant and Soil 201: 1-7.

33. Saunois M, Bousquet P, Poulter B, Peregon A, Ciais P, Canadell JG, Dlugokencky EJ, Etiope G, Bastviken D. 2016. The global methane budget 2000 - 2012. Earth System Scientific Data 8: 697-751.

34. Schäfer A, Barthelmes A, Joosten H, Kaffke A, Koska I, Schröder J, Succow M. 2005. Erlenaufforstung auf wiedervernässten Niedermooren (ALNUS-Leitfaden).

35. Schindler T, Mander Ü, Machacova K, Espenberg M, Krasnov D. 2020. Shortterm flooding increases $\mathrm{CH}_{4}$ and $\mathrm{N}_{2} \mathrm{O}$ emissions from trees in a riparian forest soilstem continuum. Scientific Reports 10: 1-10.

36. Schröder P. 1989. Characterization of a thermo-osmotic gas transport mechanism in Alnus glutinosa (L.) Gaertn. Trees 3: 38-44.

37. Siegel AF. 1982. Robust regression using repeated medians. Biometrika 69: 242-244.

38. Sun CL, Brauer SL, Cadillo-Quiroz H, Zinder SH, Yavitt JB. 2012. Seasonal changes in methanogenesis and methanogenic community in three peatlands, Newyork State. Frontiers in Microbiology 3: 1-8.

39. Terazawa K, Ishizuka S, Sakata T, Yamada K, Takahashi M. 2007. Methane emissions from stems of Fraxinus mandshurica var. japonica trees in a floodplain forest. Soil Biology and Biochemistry 39: 2689-2692.

40. Terazawa K, Yamada K, Ohno Y, Sakata T, Ishizuka S. 2015. Spatial and temporal 
variability in methane emissions from tree stems of Fraxinus mandshurica in a cooltemperate floodplain forest. Biogeochemistry 123: 349-362. Minkkinen K, Moore TR, Myers-Smith IH, Nykänen H, et al. 2014. A synthesis of methane emissions from 71 northern, temperate, and subtropical wetlands. Global Change Biology 20: 2183-2197. S, Zhang YH, et al. 2016. Methane emissions from the trunks of living trees on upland soils. New Phytologist 211: 429-439. J, Negassa W, Zak D, Urich T. 2020. Long-term rewetting of three formerly drained peatlands drives congruent compositional changes in pro- and eukaryotic soil microbiomes through environmental filtering. Microorganisms $\mathbf{8}$. priming of soil organic matter and methane production in peat soils. Soil Biology and Biochemistry 81: 98-107. 